\title{
What is Federalism?: On Piccone's Late Political Philosophy
}

\author{
Robert D'Amico
}

Paul Piccone thought, wrote, and argued polemically. It is not surprising then that the journal Telos often shared this style. The context of the journal's birth is that Piccone found himself in the academic world of the United States where there was dogmatic opposition to a tradition and intellectual movement that still survived in Europe. I will call this tradition philosophical idealism, and I think that it was the central accomplishment of Telos to have promoted the study of it and to have kept it breathing in a period when it was thought to be largely dead and buried.

My comment may seem quite odd and even bizarre to some readers of the journal since it is more common to think that the journal promoted and defended philosophical Marxism and the Frankfurt School, and of course those traditions published by the journal were critical of idealism. I am not denying that those matters loomed large in the journal's early years. But it is my view that to understand the journal's evolution and transformation from roughly 1968 until 2004 (and of course those of Piccone himself) is to understand that a version of idealism predominated and often provided the intellectual prism through which these other traditions were viewed and then assessed.

I think my claim becomes clearer in Piccone's late writings on politics and those are my topics in this article. The role of Marxism and critical theory had largely faded by the time of these writings, at least in my opinion, and even when Piccone touches on them they are read through his own version of Hegelian idealism.

I am making an ambitious claim about both the journal and Piccone's intellectual career, and I am only providing some defense of it with regard to ideas Piccone sketched within the last decade. But in part I am doing so because of why I think idealism has become more central and important over time. I offer two general reasons for its importance and then a third reason specific to my topic.

In general, idealism is a richer and more comprehensive philosophical view than either Marxism or critical theory. Also, Marxism and critical theory were explicitly or implicitly pulled toward "philosophical eliminativism.”[1] I am excluding that from my discussion here.

A second general reason is that philosophical idealism has made a sudden and intriguing reappearance within mainstream philosophy. [2] It has done so because there is a revival in the importance of fundamental metaphysics in philosophy and because challenges to physicalism are based on a current broader understanding of metaphysics. These approaches were, however, not part of mainstream philosophy during Piccone's editorship of the journal.

But specifically I want to show in some detail here how important idealism is to Piccone's unique and important insights into the role of federalism and populism within political philosophy. My focus will be on the essays "Rethinking Federalism" and "Postmodern Populism" (Piccone and Ulmen 1994; Piccone 1995a). Thus, I will outline a way to defend the metaphysics of society behind Piccone's view.

Piccone's reasons for marrying federalism with populism are his larger criticism of representative systems of democracy and defense of direct democracy.[3] Federalism is a complex political organization in which a central state exercises strictly limited control over largely autonomous federated subcommunities while those units remain federated.

Piccone and Ulmen offer two defining characteristics of federalism; it requires a right to secession and subsidiarity. Piccone and Ulmen stress that the right to secession is crucial since otherwise a federation will simply devolve into a traditional centralized nation state. Though I think this problem of devolution toward a central state 
is a challenge to most theories of federalism, I do not see how an unlimited right to secession can solve it while still preserving a stable federation.

For instance, Robert Nozick (1974) argues that self-defense alone (by a hidden-hand mechanism) will lead any set of communities to form some minimal state authority. Whether he was correct or not, the task for Piccone and Ulmen is more difficult because the question is not how to explain the necessary emergence of a "night watchman state" as a response to the thesis of anarchism, but to explain what can prevent even a limited central state from subsuming the autonomy of the federated units. Also, the problem is not practical or contingent, but theoretical. In other words, the answer that federalism might succeed just by the exercise of power or threat does not respond to the question raised nor, as I will show, coherent on its own terms.

Piccone and Ulmen define the second condition of subsidiarity as one where "only those functions which cannot more effectively be carried out on a lower level will come under the jurisdiction of the next higher level" (1994:7). I also have a concern with this second condition. As stated the condition emphasizes managerial efficiency only, and I believe such a focus would lead inexorably to the decline of federations. Thus, efficiency is not a foundational feature of federalism as a social formation (though it may be a practical fact about its stability in some circumstances, but perhaps not in others).

I now turn to the complex argumentative strategies Piccone and Ulmen offer for this view. I will be rejecting some of these strategies and my emphasis will then be, as I said, on the brief comments Piccone makes about what grounds any theory of society whatsoever. Those are the comments I will try to extend and expand upon.

First, Piccone and Ulmen offer historicist arguments in support of his conception of federalism. By historicist reasons I mean claims about how current social and political facts or conditions make federalism possible. This approach is found in the following passage.

The waste and irrationality which obtained for decades within the military-industrial complexes of both the US and the USSR ... can no longer be justified by the need to confront any imminent danger. The resulting legitimation crisis generates a problem of accountability and, ipso facto, ungovernability after it becomes clear that hitherto accepted administrative practices need no longer be tolerated ... Thus, all states today suffer from substantial democracy deficits, which precipitate rationality, motivational and fiscal crises as the state cannot possibly meet all the demands made on it by an increasingly state-dependent citizenry (1994:4).[4]

The idea here is close to classical Marxism since it depends on the notion that certain social formations must await their historical moment when, and only when, they become possible. While there is some truth to such an argument because, for example, specific forms of productivity or communication may be a precondition for some social arrangements, the question of historical contingency is not relevant to political philosophy and it is not responsive to the problem of foundation that $\mathrm{I}$ am raising in this discussion.

First, these historicist reasons rest on speculative claims about what matters of facts do prevail at any given historical moment. While classical Marxism believed that these claims had scientific answers that view is not widely held today and of course Piccone in other writings explicitly rejects it. Therefore, there is considerable room for debate about these facts or about their continuing to hold over time. But the problems of political legitimacy (what Piccone refers to in other places as the problem of preserving self-regulating traditions) ought not be held hostage to disputes about contingent matters of fact. I hope to show that there is a stronger way to support legitimacy.

Second, historicist arguments of necessity postulate an historical logic or sequence of stages in history. But these ideas are ones that Piccone explicitly rejects in other writings, and they are even rejected in other passages of the essay I am considering. I doubt then that dependence on historical stages should be considered as central.

Another strategy Piccone and Ulmen offer is to reject political philosophy as a whole and replace it with appeal to the necessity of power or force to sustain societies. Here is a characteristics expression of that view.

The bottom line is that either human rights are contractual, in which case they can be enforced only on all parties joining in the contract, or else transcendental, in which case they rate no better than a dogmatic religion and can be imposed only in the same that the Crusaders sought to convince Moslem 'infidels' of the universality of Christianity. When all is said and done, these rights can only apply if there is enough muscle behind them. Ultimately, it comes down to Thraysmachus' position anyway, and all the rhetoric about university is only meant to reassure the enforcers of the sanctity of their way (Piccone and Ulmen 1994:11).

My disagreement here is not with rejecting theories of rights as metaphysically foundational, but with the reasons given for rejecting rights.[5]

There are three weaknesses in appealing to what Piccone and Ulmen call the Thrasymachus argument. (Plato's 
character Thrasymachus in The Republic attacks Socrates by asserting that justice is simply whatever is in the interest of the strongest). First, this view is part and parcel of the so-called "value neutrality of the sciences" that Piccone, for instance, condemns when discussing John Dewey and John Rawls in other essays. Value neutrality holds that matters of social organization or political authority can be divorced from moral-political concepts such as democracy, accountability, autonomy, and freedom. I do not wish to make this concession to neutrality and in other essays Piccone is correct to dismiss it. Second, by suppressing the problem of legitimacy this line of argument can then be used to assert central state power over regional and local authorities. To embrace the Thrasymachus strategy makes the defense of federalism even more difficult. Third, it shifts the debate to matters of threat, managerial success, and thus finally utility. Again these are matters Piccone rightly criticizes in other essays when he finds them in the words of opponents. Therefore, this approach is a serious strategic error. I will have more to say below about Piccone's flirtation with moral nihilism since that position bears an internal connection to the Thrasymachus argument.

In contrast, what I consider the promising strategy lies in those fleeting passages where Piccone turns from practical and supposedly factual matters to the question of how theories of society are grounded fundamentally. Piccone speaks of the "organicity" of communities and treats that feature as constitutive of political life and individuality. He describes this underlying order of society as the internalization of "collectively shared rules and regulations concerning social behavior, conflict resolution, general expectations" (Piccone 1995a:53). This idea leads to the following complex claim.

At the national level, the rules of the game can only be formal, codified, and, therefore, incomplete, since they necessarily miss the lebensweltliche pre-formal dimension of being, while in organic communities face-to-face interactions, tradition, custom, and other extra-conceptual modes of communication remedy such inadequacy by complementing the merely conceptual (Piccone 1995a:53-54).

Piccone discusses in different contexts the advantages of this foundational approach over neo-Kantianism, pragmatism, and what he broadly calls "Enlightenment hubris" about political theory. But the content of the above claim is neither made fully clear nor developed. Piccone's case depends then too heavily on his intuitions, rhetorical devices, and promising, but largely undeveloped appeals to what he calls in several places "non-conceptual realism." This version of realism motivates his conclusion that theoretical reasoning and conception cannot be adequate to reality. I will have more to say about it as well below.

To introduce the discussion to follow I must now lay out as clearly as I can where Piccone and I disagree on these broader matters. These points cannot, of course, be fully addressed here, but I briefly review them, because if I can provide at least the sketch of a social metaphysics, then perhaps these disagreements loom less large and can be set aside.

First, I am discussing problems of political philosophy, and I consider them part of moral philosophy. Also, political philosophy is not reducible to the social sciences (it is not reducible to economic theory, for instance). Philosophical Marxism (especially the version that held sway over many European intellectuals during the cold war) treats moral philosophy (and philosophy as a whole) as an ideology and understands itself as proposing either a science as opposed to an ideology or a critical theory. For example, if Marx's theory were a science, then moral philosophy would be irrelevant. In contrast if Marxism is a critical theory, then objections are raised against moral philosophy (and perhaps philosophy as a whole) based on various historical and deconstructive arguments. Piccone of course belonged early in his career to the critical theory group.

Marx's work and the Marxist tradition is too large a topic for this paper. Suffice it to say that both aspects (the scientific as well as that of critical theory) can be found in Marx's later writings. Certainly Marx saw himself as contributing to economics, a field he took to be a science, and he understood economics as providing underlying causal explanations for historical events, thereby making possible a science of history. At the same time, but largely in passing, Marx raised general philosophical issues about mind-dependence, determinism, social kinds, and materialism. He also appealed to moral notions (again implicitly) in reaching judgments about whether social relations were just, equitable, or humane. But Marx does not discuss nor defend either his scientific or critical perspectives. [6]

I now turn to the possibility that all of moral philosophy (and thus political philosophy) is an illusion. Arguments for moral nihilism are quite rare, but Nietzsche is perhaps the classic example of the view. As shown above, Piccone considers the Thrasymachus objection to Socrates when rejecting theories of rights. He also often flirts with moral nihilism as a result. He cites, for instance, some limited agreement with Michael Foucault, and Foucault seems to have carried on Nietzsche's project of rejecting ethics by tracing ethics back to psychological formations and rationalization. I will briefly give reasons for resisting this approach. 
Of course the key concept of power that is supposed to replace the moral concepts is often left vague in these accounts. If we take Michel Foucault as an example then he defends the following views: realism is false; there are no natural or social kinds; incarceration of the mentally ill is unjustified because there is no such disease as mental illness; punishment of criminals is based on pseudo-scientific theories in law and psychology. Are Foucault's views strategies of power? [7] Does he have reasons for these conclusions other than the opportunity to exercise power? If his views are just strategies within the struggle for power, why ought we to accept them? If they are not, why are they not? Foucault dismisses the proclamations of various medical or legal authorities as masked claims to power. Does he exempt himself and if so how does he?

But even if moral nihilism can be formulated in a fashion that is not self-refuting, it is based on highly controversial assumptions about both ethics and metaphysics. Without entering into these debates, the point is that moral nihilism remains as speculative and controversial as the various biological, religious, or philosophical theories it claims to overturn and subvert. Thus, I will set this view aside and look for some further clarification and defense of the metaphysical foundations Piccone hints at in his discussion of federalism.

\section{Metaphysical Foundations}

I aim to provide a foundation for political theory outside factual matters, historical stages, power, or rights. Further, I will try to show how this approach entails a certain criticism of cosmopolitanism.

Recently philosophers from different camps (Habermas 1990, 1994; MacIntyre 1981; Taylor 1975, 1985, 1994) have offered defenses of Hegel's politics and ethics, and specifically emphasized Hegel's criticisms of Kant. But I will focus on F. H. Bradley (1951) and his attempt to revive key features of Hegel's political philosophy. Bradley was among the most prominent and productive of the British neo-Hegelians. His attempt to sketch an idealist theory of politics and ethics, influenced by both Kant and Hegel, has particular relevance to a fuller consideration of what might have motivated Piccone's views, as well how to defend such views. He is not the only idealist philosopher of importance, nor even perhaps the most impressive, but his insights into political theory are worth a closer hearing.

After I have presented my defense I raise three objections that I think are difficult for Piccone's version of federal-populism to overcome. These objections, if I am correct about them, suggest that the problems that this position intends to address cannot be solved by either political philosophy or procedural reform alone. Thus, I am a pessimist in the end about Piccone's federal-populism.

\section{Ethical Community}

Bradley begins with an argument against the notion of pleasure for pleasure's sake as a moral good. He points out that if pleasure were a good in and of itself, then it would not matter how the pleasure was realized for any given agent. But Bradley responds that if some pleasures are such or are realized in such a way that they require that the agent relinquish his autonomy or produce the agent's heteronomy, then they are not morally good. Thus, pleasure cannot be intrinsically good.

Though I will not say more about this clever argument, it should be noted that it leads Bradley to offer the agent's self-realization as the proper goal of moral and political life, and I will return to this idea below. We should recall in this context that Kant also opposed utilitarianism and hedonism and Kant was a critic of powerful nation states since he held that the nation state ought not to use coercion to promote happiness or well-being. To do so, Kant held, is to deny citizens their moral and political autonomy. The question then is why Bradley thinks he needs to modify Kant's argument against the paternal state further.

The central reason is that Bradley rejects Kant's basic concept of duty. He argues against Kant's defense of duty for duty's sake and Kant's idea of the formal necessity of the moral law.[8] I should note here that Piccone's defense of his view also rests upon the inadequacy of abstract concepts of duty or morality. Piccone, like Bradley, intends to respond to "Enlightenment hubris."

As Bradley puts his concluding points against Kant, "A will which does not act is no will, and every act is a particular event; an act is this or that act, and an act in general is nonsense ... To act you must will something and 
something definite. To will in general is impossible, and to will in particular is never to will nothing but a form ... Will, when one wills nothing in particular, is a pure fiction' (Bradley 1951:91-92).

Bradley tries to overcome this clash between the deontological and utilitarian pictures of state power by adapting parts of Hegel's political theory. For Bradley what makes an action moral is the will or intent of the agent, not the effects or consequences of the act. However, given Bradley's criticisms of Kant, he argues that ethical obligations have to be specific actions or duties and that the specificity of the action requires conditions within the surrounding world that allow for such agency. Persons have to be the kind of beings who can act and the institutional superstructure of society provides both the occasion and possibility of that agent's self-realizing actions.

The pure logical form of the moral law is not then enough nor does it provide proper moral motivation. " A more psychological consideration leads us still to the futility of duty for duty's sake. A will which does not act is no will, and every act is a particular event; an act is this or that act, and an act in general is nonsense" (Bradley 1951:91).

Hegel held that the nation state, while being the culmination of political organization, is not foundational for society. Rather, nation states are themselves founded upon and constituted by families, communities, and civil society. The existence of these pre-state formations is necessary for any political order whatsoever and by extension moral agency itself. As Charles Taylor (1985) argues, Hegel's views are Aristotelian in orientation and thus stand outside the divide between deontology and utility that has shaped modern moral philosophy.

Bradley's Hegelianism then takes the good will as aiming at an agent's self-realization by way of concrete duties and acts: "It is the self-realization of each member because each member cannot find the function which makes himself, apart from the whole to which he belongs, to be himself he must go beyond himself, to live his life he must live a life which is not merely his own, but which, nonetheless, but on the contrary all the more, is intensely and emphatically his own individuality" (1951:100).

This idea of "organicity," as Piccone calls it, leads Bradley to stress how the surrounding social world must be such that an agent can achieve concrete identity. Bradley states, "In short, man is a social being; he is real only because he is social, and can realize himself only because it is as social that he realizes himself" (1951: 111).

Bradley then takes the discussion to a new and important problem. He asks how such action can escape "the capriciousness of circumstances." This question may seem at first perplexing. How can Bradley both demand concreteness and specificity of actions while also demanding that actions not be capricious or circumstantial? Is this not an impossible demand? But this question is similar to the one I raised above with regard to Piccone's reliance on factual contingencies or historical stages as providing foundations for federalism. I was holding that force or power is not adequate to the task of foundation because it is a capricious circumstance.

Bradley's solution is found in his slogan "my station and its duties." [9] This view has often been unfairly dismissed because of connotations read into that phrase. Such readings are unfair since Bradley makes clear that a "station" is not a given, preordained order of society in the sense of a class or a caste. He speaks of choosing a station "according to my own liking." But his point is that a station (or what might be called a social sphere or domain) has duties pertaining to it and those duties are not up to the agent; they are objective. Bradley's point requires him to defend a modestly organic conception of the state. Stations and duties are what preserve and maintain the underlying communities and their social relations and thereby provide agents with opportunities to realize themselves through concrete actions and decisions. I call this approach Aristotelian because it sees society as intimate, communal, and made possible by personhood.

Bradley concludes by stating that "The point here is that you cannot have the moral world unless it is willed; that to be willed it must be willed by persons; and that those persons not only have the moral world as the content of their wills, but also must in some way be aware of themselves as willing this content" (1951a:113-114).

One way to understand the force and persuasiveness of Bradley's conception is to relate it to a current discussion of cosmopolitanism. Piccone challenges such views in his presentation of federalism and he thinks cosmopolitanism is one among many misguided efforts to universalize the notion of duty outside of local social order. For example, Martha Nussbaum's (1996) presentation of "world citizenship" or cosmopolitanism is also in part a defense of multicultural tolerance as well as a criticism of patriotism.[10]

Nussbaum argues that since the question of what is one's nation-state is an accident of birth, then citizenship in a national-state is not a morally relevant idea. "The accident of where one is born is just that, an accident, any human being might have been born in any nation. Recognizing this ... we should not allow differences in nationality or class or ethnic membership or even gender to erect barriers between us and our fellow human beings" (Nussbaum 1996:7). 
First, an aspect of this argument is in harmony with the federalist impulse since it contributes to weakening nation state authority as against that of the local community or local identity. But Nussbaum's argument suffers from a flaw that can be shown by the following analogy. It is an accident of birth that one has the parents that one has, but it does not follow from the contingency of parenthood that one's obligations to one's parents are not morally significant and even weighty. Thus, one has some morally relevant obligations to one's nation state just as one has some moral obligation to one's parents. What Nussbaum has called the accident of birth cannot support her stronger conclusion.

Nussbaum seems aware of this point I am making since she introduces a second argument in the article in defense of cosmopolitanism that I will call the "concentric circle of duties and responsibilities" argument. Here she holds that cosmopolitanism is compatible with the local political duties and commitments (the ones Piccone is stressing) because it should be understood as part of an expanding circle of responsibilities and loyalties ending with humanity as a whole.

This argument is, however, weaker than the accident of birth argument. It does not, for instance, support the Stoic view that Nussbaum claims as her inspiration and that she summarizes as holding "we should give our first allegiance to no mere form of government, no temporal power, but to the moral community made up by the humanity of all human beings (1996:7).

While we may agree then that we owe some moral consideration to humanity as whole, the problem is that it is difficult to specify what those duties are. We should now recall Bradley's point about how duties have to be concrete, specific and able to be willed. Furthermore, if there is some vague duty to humanity as a whole, the question is whether it trumps the specific and concrete duties at the lower levels of the expanding circle. Therefore, the problem with concentric expanding responsibilities with regard to Piccone's project is that duties lower in the concentric circle are precisely foundational. At least they are if the metaphysics of social being outlined above is correct. They are thus not just stronger, but specific and fundamental. In addition, they are resilient duties and less likely to issue in unintended or irreparable harms that are the obvious danger of vague cosmopolitan duties.[11]

Nussbaum's contrast in her lecture between the morally defensible cosmopolitan and the morally culpable patriot is therefore misleading. Even if for purposes of argument there is some status of world citizenship, the idea could hardly be used to supplant or lessen obligations incurred at close, immediate circles. That is especially the case if acting from the vantage point of world citizen were at the expense of local, specific duties. There are, of course, negative connotations to the word patriot, implying as it does that the person's obedience is blind and reactive. But that is a moral failing separate from the issue of what duties one ought to consider binding. A person who sought release from his immediate and local duties and responsibilities would not, I suspect, be seen as an admirable world citizen but as a local scofflaw. This result would especially be the case if duties to humanity were abstract and potentially dangerous.[12]

In contrast then to Nussbaum, there is Bradley's specificity and realism leading him to a resolute suspicion of projects that detach the moorings of society from the fundamentals of agency. "Everybody knows that the only way to do your duty is to do your duties; that general doing good may mean doing no good in particular; and so none at all, but rather perhaps the contrary of good. Everybody knows that the setting out, whether in religion, morals or politics, with the intent to realize an abstraction is a futile endeavor; and that what it comes to is that either you do nothing at all, or that the particular content which is necessary for action is added to the abstraction by the chance of circumstances or caprice. Everybody suspects, if they do not feel sure, that the acting consciously on and from abstract principles means self-deceit or hypocrisy or both" (Bradley 1951:91).

\section{Three Problems}

If I am correct, the account above defends Piccone's thesis linking together his views about political organization and decision-making as motivated by core, foundational concerns over accountability and freedom of action. My questions now concern whether this view can ameliorate the problems that gave rise to it.

The basic insight of federalism is that subunits federate underneath a central state but with significant restrictions on the power of the central state over the federated units and significant autonomy for these communities to develop their own ways of life. The glue that holds the federation together is that the central state functions to defend and protect the units, but no more. For example, military defense and perhaps some control over general conditions of 
citizenship belong to the central state. Such then are the minimum conditions for a federation.

Obviously, federalism aims at some perhaps difficult to define point between, at one extreme, the threat of a despotic central state and, at the other extreme, devolution into scattered groups that fail to cohere as a federation. But this midpoint (and of course there may be several such possible midpoints) is not only difficult to specify in practice but difficult to capture theoretically. This matter will arise in my criticisms.

The concept of populism, as Piccone admits, has been used in many diverse ways, but his use of the term is wholly with respect to direct democracy via majority rule. Thus, it is opposed not only to representational democracy, but also to weighting decisions with respect to minority preferences.

One should notice, at first, that populism so stated might well be at odds with federalism. The reason for this tension can be seen in considering a traditional picture of how populist democracies differ from liberal democracies. They differ, it is often argued, on whether or not rights (however they are defended) act as constraints on majorities. Even assuming for now that citizens always vote their interests (more about that problem below), the idea is that majorities ought not to be allowed to restrict freedom in some range of specified matters.

For example, majority votes ought not to be able to specify whether men should have beards or not, what books adults should or should not read, or what religious faith citizens should or should not have (or whether they ought to have such a faith at all). If populism enthrones the decisions of majorities as definitive, then such rule could conceivably be used to weaken the autonomy of federated units. Majority votes could simply stipulate what other federated states can and cannot do thereby ending the point of federalism itself.

Therefore, I think a proponent of such a combination of federalism with populism must intend that the majorities that rule in the sub-units cannot be aggregated to create in effect nation-state super majorities. The federated units must be protected and thus understood as free to develop what John Stuart Mill called "experiments in living." [13]

Why, then, add populism at all? I think the motivation for it remains the accountability of decisions within each federated community. The idea is that voting by the direct decision of each and every citizen neither dilutes nor bargains away that authority. Thus, as long as the central-state cannot use aggregated majorities against other federated units, the federated units still ought to act by direct democracy so to limit the authority of representational decisions and maintain strict accountability for their own decisions.

Let me briefly summarize my defense of this view before proceeding to my three criticisms. Bradley provided an important part of the defense. Certain arrangements of society provide the basis for self-realization. In this way, agents may alter their lives as they gain experience and as society provides them concrete opportunities to act. The close surrounding social world protected from distant authority provides the right balance of security with such active citizenship. I suggested that we label such an approach as Aristotelian-Hegelian, and we could call the kind of society resulting from it Republican.[14] I think the passages Piccone wrote on the preconceptual features of social life and the need for open-ended projects of life within society are captured by this defense.

The first problem I will raise is a regress objection. By a regress objection I mean that the problem that motivates federalism as a solution can be seen replicated at another level. Piccone names the problems that federalism responds to as alienation, loss of individual freedom, arbitrary rule, and illegitimacy.

I will focus on the idea that federalism preserves freedom and accountability. Federalism does so by devolving authority and decision-making to smaller and nearer communities. Thus, immediate proximity is the key. It also preserves diverse ways of life by standing as a veto against large-scale planning.

But my criticism is that federalism gives at best only the appearance of legitimacy by having majority decisions local. If we want the decisions to be legitimate, then we need to ask what makes a decision legitimate whether near or far. But to that question federalism gives no clear answer. In Piccone's account it is taken to be legitimate by simple fiat or stipulation. This point is reflected in how he defends and incorporates the role of populism. But even direct democracy does not necessarily preserve either accountability or freedom. While Rousseau could simply and infamously declare that whatever the general will decides must be free, I assume such question begging is no longer acceptable. While Piccone is justified in saying that a political theory cannot accommodate the details of actual life and contingent circumstances, that does not speak to this question. If majority decisions are definitive and unlimited in range, then what makes them also legitimate?

The second problem arises when considering that perhaps federal-populism simply confers legitimacy by way of the autonomy of each federated unit. Piccone does set the bar for autonomy very high by allowing for the unrestricted right to secession. Of course he does not explain why the notion of such an unlimited right arises 
especially after Piccone, as shown above, also attacks the very notion of rights. But even if that problem can be set aside, the basic idea of a majority vote is now critically ambiguous. It has at least three different meanings. It can simply mean rule by a majority or it can mean rule by what the majority of voters in fact want or prefer. But it has been known and discussed for some time that these two senses of majority rule are distinct and can come apart. What that means is that a majority vote may not in fact result in producing a majority's actual preference. Hence, in this fashion the device would undermine accountability as well as freedom. Third, majority voting can mean, as I said above, that the majority rules only in some areas of decision-making but not in all areas. This meaning seems to be the one Piccone is willing to bargain away in constructing his view and I consider that a serious weakness.[15]

At this point then federalism becomes a "bait and switch" maneuver. It speaks of a certain central decisionmaking as destructive because it erodes local autonomy and threatens despotism and tyranny. Representative procedures that make for these decisions, it is argued, will in the long run overturn the diversity, stability, and engagement that are the hallmarks of communities. I have called this picture Aristotelian and even Hegelian, since defenders of the state can appeal to it. Bradley, as I said, gives this picture its best defense and a defense that steers away from strong central state power.

But when switching to the local level, the very same problem arises since there the will of the majority is definitive. Why is a local majority always preferable to a representative majority? It may be possible to give reasons for advocating the tyranny of the local majority, but then not by simply invoking the threat of state tyranny. After all, those in the minority have their self-realization held hostage to the vagaries of local majority approval, distant state tyranny not withstanding.

For example, experiments in living, as Mill argued, immediately confront the intolerant neighbor. Mill's concern seems if anything more pressing today since there are now more ways to express "neighborly" intolerance of others and the scope of those who are one's neighbors grows with the power of communication technologies. Piccone, I suspect, would agree with my invoking some historical conditions at this point. But to then condemn the distant bureaucrat so as to enthrone the local magistrate is a failed solution.

The third problem concerns an aspect of the Aristotelian-Hegelian defense of federalism. I will just discuss Aristotle for the moment. Aristotle argues, as I said, that there must be preconditions for any society whatsoever. He also defends the idea of a ranking or hierarchy of ways of life. What he means is that certain beings are capable of practical reasoning, but once that capability arises then ways of life are judged better or worse. I think Piccone has exactly this point in mind when he defends the importance of both autonomy and self-reliance. Social beings are not neutral between the ways of life available to them.

This kind of analysis has two important implications. On the one hand, it can challenge those ways of life that erode these preconditions. For instance, the notion of a dystopia rather than a utopia (often found in fictional literature) represents such an erosion. But actual conditions such as extreme famine, violence, or repression may likewise serve to remove the possibility of social formations. On the other hand, this kind of analysis also raises the question of what is needed to preserve societies and personhood.

Defenses of federalism, such as given by Piccone, go directly from the preconditions for personhood to the proper decision-making. For example, Piccone argues that small-scale communities provide the preconditions for personhood; and, he thinks majority votes or even unanimity is thus the proper form of decision-making. But while we may agree that for there to be a society there must be persons, we may not agree on what produces persons nor on whether that process supports such and such a social arrangement.

For example, paternalism (to varying degrees of course) may well be part of what turns children into persons, but that point hardly supports paternalism for society as whole. Mill makes a persuasive case for how paternalism damages personal autonomy -- a case echoed in Piccone's warning that welfare states produce "citizen clients." Paternalism is also Mill's central reason for condemning the growing power of nation states.[16]

The debate has moved in a circle. Federalism in trying to challenge central state paternalism gives unbridled rule to local majorities. It supports, in effect, local paternalism. While Piccone's motivation was to maintain the social formation of federated communities, by appealing to stability, protection, and making judgments definitive (rather than the concept of legitimacy) his strategy ends up defending and expanding the case for central state power.

Of course I have not shown that no defense of these views is possible; nor have I responded to every version of federalism. I hope I have shown the need for a deeper defense and how the strategy of simply stipulating consistency with political procedures or general principles is inadequate to the issue. Piccone's federalism promises something theoretically substantive; namely, it promises to motivate what is required for a proper or just society.

But I do not see how a political philosophy could have the result that it required federalism. Rather, federalism 
may be the type of social organization compatible with different political philosophies, or it may simply be a type compatible with what Bradley called capricious circumstances. That should not come as a surprise since the appeal of federalism is its "let a thousand flowers bloom" vision of society. But then that liberality is precisely the problem with it since this tolerance for diversity in social arrangements and values could precisely be what is corrosive to the preconditions for public life; and public life is what federalism claimed to defend above all else.

\section{Endnotes}

1. By this term "philosophical eliminitavism" I mean arguing that philosophical issues are pseudo-problems, or disappear into the sciences, or are linguistic errors, or are historical ideologies. Piccone was not entirely unfriendly to the historical ideology account, unfortunately in my opinion. These opinions have become gospel within the academic world and are promoted by postmodernists, pragmatists, and positivists alike (for different reasons of course).

2. I cannot provide an adequate definition of idealism (or metaphysical foundation) for this presentation and obviously there are different types of idealism in philosophy. Also this article is not an attempt to defend or criticize idealism. Piccone's comments about nonconceptual realism should be understood as compatible with a range of metaphysical positions, idealist and materialist. In this article the forms of idealism closet to Piccone's project are Hegelian and Aristotelian. But this passage from David Chalmers gives something of the view I have in mind. "There is a sense in which this view can be seen as a monism rather than a dualism. but it is not a material monism. Unlike physicalism, this view takes certain phenomenal and protophenomenal properties as fundamental.... It is an idealism very unlike Berkeley's, however. The world is not supervenient on the mind of an observer, but rather consists in a vast causal network of phenomenal properties underlying the physical laws that science postulates" (Chalmers 1996:155). For further discussion see Foster 1996.

3. "Popular participation alone is not sufficient to qualify any movement as populist. The sine quo non of populism is a living dialectic between individual and community, whereby the first internalizes the norms of the latter while subsequently enriching and reproducing them. The role of Islam in the Iranian revolution may contribute to an understanding of its fervor and energy, but it does not lead to the conclusion that the regime it brought o power has anything to do with populism." (Piccone and Ulmen 1995c:8) In another context Piccone holds; "In other words, the populist politician's distinguishing feature is direct access to the very precategorical dimension rationalist and liberals dismiss as 'irrational' and, consequently, responsible for most of the major 20th century authoritarian involutions" (Piccone 1995a:53). The appeal to a "living dialectic" or the access to the "precategorical" are not foundational arguments in my view, but I do agree that popular participation is not a sufficient condition. Piccone's appeal to majority rule is a concrete way to address this question of sufficiency and I discuss it further in my criticisms.

4. "Today, when the premodern conditions conducive to these disastrous authoritarian outcomes no longer obtain within most of the industrialized world, the prospects of populism as a viable political alternative may be much brighter than at any time in the past. This is also facilitated by the fact that, within the crisis of modernity, the New Class has entered a phase of delegitimation and decline. As a result, the populist antimodernism assumes an altogether different meaning. In an age of postmoderntity, after the collapse of the concept of progress has undermined all unilinear theories of history and dethroned modernity as the ultimate achievement of civilization, the populist rejection of modernity, hitherto regarded as a sign of backwardness and immaturity, now becomes merely another political choice" (Piccone 1995a:49).

5. In discussing a theory of rights Piccone and Ulmen state; "Ultimately 'human rights' fare no better than any other set of values accepted by any other people for whatever reasons ... To impose them on communities that do not accept them is nothing more than act of cultural imperialism ... Confronted with the objection, Johnstone throws up his hands and claims that historical and cultural particularity do not invalidate universality. But can he prove that, in a situation in which universal rights are not actually universally accepted, other than by claiming that he regards these rights as universal? Doing so implies a shift to Thrasymachus' relativism from his initial Socratic universalism. True universalism can not be a matter of metaphysical deduction. It is the result of de facto universal acceptance of particular norms. One single dissenter invalidates the claim" (Piccone and Ulmen 1994:p. 11). Though I agree that a theory of rights does not admit of direct proof (like any matter of political philosophy it is simply more or less coherent with other foundational claims), this criticism of rights has two problems. First, Piccone and Ulmen do not distinguish universal claims from unanimous claims. Universality is a matter of the scope of the claim, not a matter of how many agree to it. A single dissenter does not refute a universal claim any more than a single dissenter refutes the universal law of gravity. A law or universal claim can, of course, fall to arguments against its coherence or recalcitrant facts, but those matters are not about the number of votes. Second, this idea of a single dissenter invalidating a political decision 
would then directly weaken Piccone's later argument for definitive majority rule at the local level. Since that is his central idea for defending populism, I will set aside this passage as curiously anomalous. I have more to say about dissent in my criticism of Piccone's federalism.

6. Part of the reason for this lack of defense probably rests with Marx's false belief that he had shown how capitalism would inevitably collapse due to an intractable problem in the appropriation of surplus value. Perhaps he took that supposed fact of economics concerning the limits to profit and the inevitable fall in wages as allowing him to postpone clarification of his moral criticism or the other problems in philosophy of science. For further discussion see D'Amico 1989.

7. A fuller discussion with references can be found in D’Amico 1999:199-230.

8. " $[\mathrm{T}]$ he categorical imperative alone can be taken as a practical law ... because what is necessary merely for the attainment of an arbitrary purpose can be regarded as itself contingent, and we get rid of the precept once we give up the purpose, whereas the unconditional command leaves the will no freedom to choose the opposite. Thus it alone implies the necessity which we require of a law" (Kant 1969:43). In Kant's technical language, then, moral laws are synthetic a priori judgments.

9. Hegel's comments on public opinion exhibit the idea that Bradley is developing. "Public opinion, therefore, contains within itself - in the form of healthy human understanding - the eternal, substantial principles of justice, the true content and result of the entire constitution, all legislation and the universal condition on the whole ... The principle of the modern world requires that whatever I am to recognize shall reveal itself to me as something justifying recognition ... Once one has had one's say, and so one's share of responsibility, one's subjectivity has been satisfied..." (Hegel 2002:245246).

10. Bradley dismisses what he calls "cosmopolitan morality." "Men nowadays know to some extent what is thought right and wrong in other communities now, and what has been thought at other times; and this leads to a notion of goodness not of any particular time and country"(Bradley 1951:139).
11. Not only is it difficult to state what an obligation to all of humanity would require one concretely to do, but also even acting to assist the destitute poor, for instance, may be inconsistent with a vague duty to all of humanity. In fact, cosmopolitanism, in the way Nussbaum defends it, appears to work against an expanding concentric circle of responsibilities since she treats duties to humanity as always predominant.

12. Bradley's criticism is of duties not connected to concrete circumstances that realize and determine them. "And since the principle is a formal empty universal, there is no connection between it and the content which is brought under it"(Bradley 1951:94).

13. "[T]hat there should be different experiments in living; that free scope should be given to varieties of character, short of injury to others; and that the worth of different modes of life should be proved practically, when anyone thinks fit to try them ... but the evil is that individual spontaneity is hardly recognized by the common modes of thinking as having any intrinsic worth, or deserving any regard on its own account. The majority, being satisfied with the ways of mankind as they are (for it is they who make them what they are), cannot comprehend why these ways should not be good enough for everybody" (Mill 1978:54).

14. The term Republican here of course refers not to a political party but to the Roman and Renaissance concept of the political community. For further discussion see Pettit, 1997 and D'Amico 2000.

15. John Stuart Mill's On Liberty (1978) is an extended argument in defense of the third meaning of democratic voting with respect to what Mill calls "self-regarding actions." Mill defends this view in terms of both its expansion of freedom but also because it defends autonomy against mass conformity.

16. "The mischief begins when, instead of calling forth the activity and powers of individuals and bodies, it [the State] substitutes its own activity for theirs; when, instead of informing, advising, and upon occasion, denouncing, it [the State] makes them work in fetters. Or bids them stand aside and does their work instead of them" (Mill 1978:113).

\section{References}

Appiah, A. K. 2006. Cosmopolitanism: Ethics in a World of D’Amico, R. 1989. Historicism and Knowledge. New York: Strangers. New York: W.W. Norton and Company. Routledge.

Bradley, F.H. 1951. Ethical Studies: Selected Essays. Indianapolis: Bobbs-Merrill Company.

1999. Contemporary Continental Philosophy. Boulder, Colorado: Westview Press.

Chalmers, David J. 1996. The Conscious Mind: In Search of a Fundamental Theory. Oxford: Oxford University Press.

2000. “Holistic Republicanism." Telos 117: Winter, 183-192. 
Foster, John. 1996. The Immaterial Self: A Defense of the Cartesian Dualist Conception of the Mind. New York: Routledge.

Habermas, J. 1990. Moral Consciousness and Communicative Action. Translated by Christian Lenhardt and Shierry Weber Nicholson. Cambridge, Massachusetts: MIT Press.

-.---. 1994. "Struggles of Recognition in the Democratic Constitutional State." Pp. 107-148 in Multiculturalism: Examining the Politics of Recognition, edited by Amy Gutman. Princeton, N.J.: Princeton University Press.

Hegel, G.W.F. 2002. The Philosophy of Right. Translated by Alan White. Newburyport, MA.: Focus Philosophical Library.

Kant, I. 1969. Foundations of the Metaphysics of Morals. Translated by Lewis White Beck. Indianapolis: Bobbs-Merrill Company.

MacIntyre, A. 1981. After Virtue: A Study in Mortal Theory. Notre Dame, Indiana: University of Notre Dame Press.

Mill, J. S. 1978. On Liberty. Hackett Publishing Company.

Nozick, R. 1974. Anarchy, Utopia and the State. New York; Basic Books.

Nussbaum, M. 1996. "Patriotism and Cosmopolitanism." Pp. 2-21 in For Love of Country: Debating the Limits of Patriotism, edited by Joshua Cohen. Boston; Beacon Press.
Pettit, P. 1997. Republicanism: A Theory of Freedom and Government. Oxford: Oxford University Press.

Piccone, P. and G. Ulmen. 1994. "Rethinking Populism.” Telos 100: Summer, 3-16.

-----. 1995a. "Postmodern Populism." Telos 103: Spring, 45-86.

---.. 1995b. "Populism and the New Politics." Telos 103: Spring, 3-8.

------. 1995c. "Introduction to Special Issue on Populism II." Telos 104: Summer, 3-12.

Piccone, P. 1995d. La Revoluzione Federaliste: Con Un Saggio di Gianfranco Morra. Rome: Settimo Sigillo.

Taylor, C. 1975. Hegel. Cambridge: Cambridge University Press.

-----. 1985. "Hegel's Philosophy of Mind." Pp. 77-96 in Human Agency and Language: Philosophical Papers 1. Cambridge: Cambridge University Press.

-...-. 1994. "The Politics of Recognition." Pp. 25-73 in Multiculturalism: Examining the Politics of Recognition, edited by Amy Gutman. Princeton, N.J.: Princeton University Press. 
